\title{
The Webster key
}

\section{Margaret E. DeWitt}

To cite this article: Margaret E. DeWitt (1922) The Webster key, Quarterly Journal of Speech, 8:2, 156-160, DOI: $10.1080 / 00335632209379376$

To link to this article: http://dx.doi.org/10.1080/00335632209379376

$$
\text { 曲 Published online: } 06 \text { Jun } 2009 .
$$

Submit your article to this journal

\footnotetext{
LII Article views: 4
}

Q View related articles $₫$ 


\section{THE WEBSTER KEY}

\section{MARGARET E. DEWITT}

New York City

$\mathrm{H}^{\mathrm{AVE}}$ you ever looked at old keys in the Metropolitan Museum? H Some are of beautiful, intricate workmanship, others almost austere in their massive simplicity; some are large, others small. Most of them give one the feeling that the master workmen knew what they were about when they were making these keys. At times when I think of them I am reminded of the Sankrit alphabet, because of the thought, care, symmetry, and early intelligence that underlies the work.

How often it is the case that the old hand-made objects are far more wonderful than those of the in-between modern period of experimental manufacture. The keys of the latter period fall very short when compared with old ones, and they fall quite as short when compared with the modern, Yale type, keys.

The keys of the in-between period remind me of the so-called "Webster Key to Pronunciation." It certainly cannot be made to fit these modern days of "Yale" philological locks.

May one ask, in all meekness, just which pronunciation is this linguistic "Webster Key" supposed to unlock? May one also venture to suggest that when the unlocking has been completed, the sounds produced by the speaker will be the self-same ones which belong to that individual's usual dialect? If he nasalizes, he will nasalize with equal gusto after looking up the word; if he inverts his vowels so that his speech gives the general impression of an electric coffee mill revolving at top speed, then he will continue to grind out his words in the same manner after consulting Webster as he did before. There will be but one added calamity to the general noise : the man will calmly assure you that he is right, because, "Webster says so!"

There is no so-called "key," good or bad, that can help a person who uses a non-standard dialect to attain a standard pronunciation, unless the person has a clear idea what sound each symbol of the key represents. To acquire this knowledge, the person 
must be orally drilled in the separate sounds by some one who knows them, or have a detailed description of them-preferably illustrated by diagrams showing the position of the organs of speech.

As for the symbols themselves, used in the Webster Key, they were made with the good intention of helping to solve a difficulty which has never been solved by them. They have long since been put aside as inadequate, not only by scientists, but by every one having even a slight knowledge of the spoken language from the specialist's viewpoint.

I have considered it a sign of rare intelligence on the part of private tutors and other teachers, that not one imposed upon mo the Webster Key during or after childhood; and I am certain many another person feels equally grateful to have escaped the same thing.

If it is so out of date, why, then, does so splendid a book as The Webster Dictionary still cling to this key? The book is revised from time to time in other respects, why does it not turn to modern linguistic science for its sound symbols and method of dealing with the spoken language? Because editors of a long established book hesitate to throw over what has been used and advertised so extensively for so long a time. This is the simple and plausible supposition of a certain well-known philologist.

If that is the case, is it fair to the memory of the man whose name is still used far and wide in connection with this folly as if he were sanctioning it from his grave? Webster was an Americanand one meaning of American is, progressive intelligence. Had Webster lived longer he would not have stood still on this or any other important subject.

An advertisement of Webster's New International Dictionary has recently been received. It continues to stress the Key and gives much space to it. The symbols are used in The Americanization of Carver. The person who has transeribed it evidently knows something about strong and weak forms of words, because the weak forms are used in the words of, $a$, and the. What about the weak forms of such words as at, was, had, and, etc.? Who would use strong forms of the latter words in an entire spoken text? A poorly taught foreigner, perhaps, and others whose speech is equally poor; certainly not anyone using Accepted Standard English Speech. I do not mean that everyone using the accepted form of speech realizes he is 
using strong and weak forms. He may do it quite unconsciously, but he will use weak forms at certain times-and properly, too! Also; would a speaker of good English use the same vowel-sound in the second syllable of appear, as in the first vowel of eve? Certainly not.

There is no space to go into further detail. In Relative $E$ fficiency of Phonetic Alphabets, Guy Montrose Whipple gallantly defended the "Webster Key" in 1911. It did harm by influencing people wrongly; it did good by bringing to life a pamphlet by philologists entitled, The N.E.A. Phonetic Alphabet (with a review of the Whipple experiments) by Raymond Weeks, James W. Bright, Charles Grandgent. These latter names have an international reputation.

The editors of the dictionary must have read both pamphlets.

This is 1921, and the advertisements still continue to laud the misfit KEY. The following is taken from the recently received advertisement:

"The Key . . . shows the correct pronunciations, and will be easily understood because the Webster pronunciation symbols used are famillar to all. (A full list of these is given. . . . They have been adopted for nearly all the schoolbooks, $-25,000,000$ published annually and are taught in schools.)" The italics are my own.)

If especially the latter is the case, it would seem necessary to add a word to the name of a group, composed in part of well meaning men: The Sleeping Board of Education! ! ! May some fo'sy prince of Knowledge come to awaken them, and a great many ofders, who are suffering from the same sleeping sickness, before it is too late!

It is unnecessary to go into detail of the Webster Key defects becauses it has been so admirably done by the previously mentioned philologists.

This article is not written for the sole purpose of picking at "Webster." I chose The Webster Dictionary partly because it is, rightly, so extensively known and used in America and elsewhere, partly becauses the Key discussions are so unfortunately prevalent that most of us have been drawn in at one time or another. In short, Webster is almost a household word.

In case it affords satisfaction to anyone, I shall add a word about The Concise Oxford Dictionary. Splendid as it is in other respcets, it also, cannot and does not come under the heading of a 
pronouncing dictionary, as that term is understood by philologists. The day is coming when all dictionaries that lay even a slight claim to dealing with pronunciation will discard the use of cumbrous diacritical marks. They will all adopt the same alphabet of which each symbol represents one sound, and always the same sound.

Such an alphabet is the one adopted by the International Phonetic Association.

It is not flawless, but it is less full of flaws than most, and is in wide international use in linguistic text-books, etc. For general practical purpose a broad transcription is used; for comparative or more detailed work a much narrower one. That is, small modifiers indicate whether a sound should be slightly raised, lowered, moved to the front or back, aspirated or not, ete.

This alphabet is used by Daniel Jones in his An English Pronouncing Dictionary, (on strictly phonetic principles) E. P. Dutton \& Co. To use it, one must be well acquainted with the separate sounds of our speech, and the symbols which represent them. At the least, the elementary training in separate sounds should be an oral one, for no matter how well we may speak, we are not born with a scientific knowledge of speech-sounds-not even of our own language.

If it is impossible to take oral lessons it would be well to obtain the same author's An Outline of English Phonetics, which containg 131 illustrations and detailed descriptions of sounds.

It may be advisable to add a word concerning Accepted Standard English Speech.* All too often authors do not call it that for fear of antagonizing a multitude of readers, and they get around the difficulty by various master-strokes of diplomacy. Mr. Jones treads cautiously and calls it Public School Speech-a very good term for those who fully realize its English significance. But why avoid the term Standard $?$

-T. Fisher Unwin has published H. Cecil Wylde's A History of Modern Colloquial English. Those who are interested in the subject will find it a book that has a rare mingling of gcholarship and beauty. One would like nothing better than to list it under Biographies, for to some of us' English gpeech has been a life-long triend and veritable personality. In these pages one can watch the growth of its individuality; one can see how it has lived and moved and had its wondrous belng deep in the heart of past generations; and one can see how through that past it has become Its glorlous musical present personality-for the sounds of Standard English are mugical, If the speaker will but have them so. 
There was a standard of speech for Greek and Latin; there is one for French, Spanish, etc. The English one has existed for hundreds of years. Accepted Standard Speech is merely that form which has been aptly described as Free from localisms, provincialisms, and vulgarisms.

It is that form of a spoken language which passes educated, contemporary international muster, which has no glaring highlights or harrowing shadows; that form which through its beauty makes a language worthy of life-and life in its sublime sense is never merely local.

It is this form of our spoken language which every sehool owes every child and which should be taught there on a modern scientific basis of phonetics.

It is a duty of parents to demand this training for their children. It is a personal duty for all students, who have not had it in childhood, to demand it from colleges, universities, or any other educational institution. They owe it to themselves to obtain the best that is due them in the study of their own or any other language.

Institutions which do not offer these courses are thirty years behind the times, and their instruction in that line is accordingly of a counterfeit nature-perhaps unconsciously so.

Think of the amounts of printer's ink, editor's energy, public money, and brain-power, that are expended yearly to produce, promote, and consume old-fashioned keys to pronunciation!

If a tenth of these amounts were expended for the furtherance of acquainting people with the actual sounds of twentieth century spoken English, the positions of the organs of speech for producing these sounds, and a modern phonetic alphabet as symbols for the sounds, it would be an inestimable national gain, and a patriotic service for the future generations. 